\title{
Pesticide Toxicity Prevention in Farmer's Community Movement
}

\author{
Eka Lestari Mahyuni ${ }^{1 *}$, Urip Haharap ${ }^{2}$, R. Hamdani Harahap ${ }^{3}$, Nurmaini $^{4}$ \\ ${ }^{1}$ Department of Occupational Safety and Health, Faculty of Public Health, Universitas Sumatera Utara, Medan, Indonesia; \\ ${ }^{2}$ Department of Pharmacology, Faculty of Pharmacy, Universitas Sumatera Utara, Medan, Indonesia; ${ }^{3}$ Department of Social \\ Anthropology, Faculty of Social and Politics, Universitas Sumatera Utara, Medan, Indonesia; ${ }^{4}$ Department of Environmental \\ Health, Faculty of Public Health, Universitas Sumatera Utara, Medan, Indonesia
}

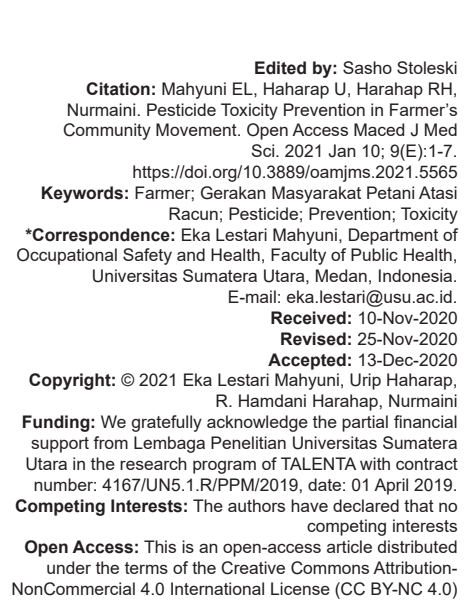

\section{Introduction}

Pesticide toxicity is a serious problem that often occurs in agricultural communities in poor or developing countries. WHO reports that as many as one million people each year will experience acute toxicity due to pesticides and its prevalence continues to increase in Nicaragua, Indonesia, Vietnam, Brazil, China, Bangladesh, Cambodia, and India. The increase in toxicity rates that occur can reach $8.5-50 \%$ annually. In general, the groups most vulnerable to pesticide toxicity are children, women, workers in the informal sector, and poor farmers [1], [2], [3], [4], [5].

Development in the agricultural sector is in line with the higher of pesticide use as an intensification technology. However, it also followed by increasing exposure of pesticide hazards to pesticide sprayers [6], [7], [8]. It is generally caused by improper use of pesticides and characterized symptoms of toxicity and low activity of the cholinesterase [9], [10], [11], [12], [13], [14].
Karo Regency is one of the highlands that were farmers as the majority occupation of the people. Based on the latest test for cholinesterase activity data conducted in 2008, it was found that there was pesticide toxicity in farmers in several regions scattered in Karo District with an average of $55.26-91.25 \%$ of all [15]. Some cases handled by Kabanjahe General Hospital occurred as many as 21 cases starting from January to October 2017, generally caused by ingestion of herbicides, pesticides Gramaxone, and Roundup [16]. This percentage shows that the risk of toxicity is very high in pesticides used by farmers in the Karo communities.

Various efforts have been made to reduce the problem of toxicity due to pesticide use. Starting from the development of Integrated Pest Control (IPM) methods, the 6T Principle (Correct Target, Correct Quality, Correct Type of Pesticide, Correct Time, Correct Dosage or Concentration and Correct Way of Use) in pesticide use, biopesticides that are in line with the organic farming system and government also launched a program called Bedah Kemiskinan Rakyat Sejahtera as an empowering 
community to improve the welfare of farmers and creating healthy agriculture [17], [18], [19], [20], [21]. To achieve the Sustainable Development Goals, goals of empowerment continues in various fields until the United Nations launched community empowerment by family farming model. It was followed by Indonesia with launching various empowerment programs such as forming independent villages, partnerships, utilizing corporate social responsibility, and establishing the Indonesian Healthy Agriculture Institute with the Healthy Farmers Empowerment program [2], [22], [23], [24], [25].

Horticulture farmers have a high-risk potential to exposure by pesticide cause the plant needs more frequency to be sprayed. The majority of Karo's communities have a high level of alliance and solidarity. The pesticide use is quite high, even farmers are very dependent on pesticides. This dependence is also in line with the risk of pesticide toxicity that can be experienced by farmers due to inappropriate pesticide use and defying to procedures. Farmers also often do not wear personal protective equipment (PPE), thereby increasing the risk of direct contact with pesticides.

It is a chronic problem that has to solve in pesticide toxicity among farmers. Therefore, the purpose of this research is to design an effort of pesticide toxicity prevention that carried out by community movement to reduce the risk of pesticide toxicity. The effort will be created with farmer community participation in action research to identify, analyze, and solve the basic problem behavior in pesticide used. Joint agreement resulting from community participation, stakeholders, community leaders, and researchers as a solution of the problem becomes an effort to prevent the risk of pesticide toxicity.

\section{Methods}

It is an applied study with a participatory action research approach cycle that carried out in look, think, and action stages to identify the behavioral risk related to the pesticide use, then analyzed to be used as a basis for formulating prevention efforts that will be carried out (evidence-based). The results of the comprehensive analysis will formulate actions step that taken on subjects and carried out by involving the active participation of the community [26], [27].

The farmers in Karo's communities' plants spread flowers, beans, carrots, potatoes, cabbage, broccoli, and chilies. Agricultural land managed by farmers is also not too large so that farmers have the potential to be empowered. The participants were taken by a purposive technique that selected by who will participate and willing to be an agent, committed, healthy, communicated, and able to work together.
Participants will participate in all activities of research to identify (look stage), analyze (think stage), and solve the problem (act stage). Data collected using in-depth interviews and focus group discussion (FGD), self-report, and participatory observation. All action was analyzed in descriptively related to a thematic analysis approach that includes conceptual analysis and relationship analysis [28]. All subjects gave their informed consent for inclusion before they participated in the study. The study was conducted by Universitas Sumatera Utara and the protocol was approved by the Health Research Ethics Committee of the Faculty of Nursing Universitas Sumatera Utara with number 1608/I/SP/2019. Ethical clearance has been proposed by giving freedom to participants (autonomy), doing good (beneficence), not harming (non-maleficence or do not harm), and confidentiality (confidentiality) of the ethical institutions.

\section{Results}

Improperly of pesticide use behavior is the basic problem in pesticide toxicity. The farmers' ignorance of the dangers and effects of pesticides always is a reason that shows the poor and dangerous of pesticide use among farmer. Based on the identification of farmers participation found that pesticide use in communities had a high risk such as direct contact with pesticides, not using protective driers, spraying while smoking, blowing pump hoses directly, and poor personal hygiene. Farmers never read the rules of pesticides used but done it according to the information in generations. As a result, farmers never pay attention to the procedures in using pesticides.

The farmers do not use personal protection even though they know it recommended. They do not feel the direct effects of the pesticides and also assume all exposure to pesticides will disappear after bathing. The farmers also disposing of pesticide leftovers around fields or ravines and being left scattered, generally store pesticides in an open bucket medium nearby the kitchen in their house, have poor personal hygiene that caused by the limited availability of water in farming, and take a bath after they have finished their field activities. The average participant has use 4-6 spray tanks for their large field with small hoses to spray. It giving more dangers of risk than using a large hose. There was inconclusive evidence for the association between occupational pesticide exposure and lung cancer (Table 1).

Based on the analysis results, it is necessary to formulate several steps that can be applied by farming communities for reducing the risk of pesticide toxicity. Intervention efforts were formulated jointly with participants who also gave roles as agents of change. 
Table 1: Matrix of risk behavior in pesticide use among farming communities

\begin{tabular}{|c|c|c|}
\hline Process in pesticide use & Hazard behavior & Toxicity effect \\
\hline $\begin{array}{l}\text { Media and spray } \\
\text { equipment used }\end{array}$ & $\begin{array}{l}\text { 1. Suck the end of the spray } \\
\text { hose } \\
\text { 2. Pressing the end of the spray } \\
\text { hose hole }\end{array}$ & $\begin{array}{l}\text { 3. Oral exposure (mouth) } \\
\text { 4. Dermal (skin) exposure }\end{array}$ \\
\hline $\begin{array}{l}\text { The type of pesticide } \\
\text { used is excessive }\end{array}$ & $\begin{array}{l}\text { Using of three-five even more } \\
\text { types at once in a day }\end{array}$ & Multicomplex intoxication \\
\hline $\begin{array}{l}\text { The process of mixing } \\
\text { pesticides }\end{array}$ & $\begin{array}{l}\text { Do not use PPE and the dose of } \\
\text { pesticides does not match with } \\
\text { packaging label }\end{array}$ & $\begin{array}{l}\text { 5. Direct contact } \\
\text { 6. By inhalation } \\
\text { 7. Splattered } \\
\text { 8. Spillage }\end{array}$ \\
\hline $\begin{array}{l}\text { The process of } \\
\text { transferring the mixture } \\
\text { to the sprayer }\end{array}$ & $\begin{array}{l}\text { Ergonomic posture (bending, } \\
\text { squatting) }\end{array}$ & $\begin{array}{l}\text { 9. Sworn } \\
\text { 10. Complaints about } \\
\text { MSDs } \\
\text { 11. Tired due to load } \\
\text { frequency }\end{array}$ \\
\hline $\begin{array}{l}\text { Pesticide spraying } \\
\text { process }\end{array}$ & $\begin{array}{l}\text { 12. Not in the direction of the } \\
\text { wind } \\
\text { 13. High spray frequency } \\
\text { 14. Effect of plant height } \\
\text { 15. Without PPE } \\
\text { 16. Spray duration } \\
\text { 17. Smoking }\end{array}$ & $\begin{array}{l}\text { 18. Splashed, inhaled, } \\
\text { ingested, and exposed } \\
\text { to pesticides } \\
\text { 19. Cumulative intoxication } \\
\text { 20. Direct exposure }\end{array}$ \\
\hline $\begin{array}{l}\text { Post pesticide spraying } \\
\text { process }\end{array}$ & $\begin{array}{l}\text { 21. Poor personal hygiene } \\
\text { 22. Dispose of the remaining } \\
\text { pesticide packaging } \\
\text { carelessly } \\
\text { 23. Store the remaining } \\
\text { pesticides in the open area }\end{array}$ & $\begin{array}{l}\text { 24. Indirect exposure } \\
25 \text {. Environmental pollution }\end{array}$ \\
\hline
\end{tabular}

Participation is carried out, starting from the formulation of the empowerment strategy to implementing the formulated actions and determining the formulation of the community movement steps. This effort created to anticipate the farmer's opinion and requires a social movement that can provide change for the farming community. Awareness of the dangers of pesticides is the first point that must be instilled in their minds. Even though farmers do not consider it to have any effect, farmers have to aware that they are likely to experience chronic poisoning due to the use of pesticides for long periods (Figure 1).

The participation of farmer communities showed the learning by doing process to reach daily habits. It makes it easy for to farmers be aware of the problems and decrease improper of pesticide use. FGD concluded that the intervention of pesticide toxicity is manifested in the social movement that called Community Movement in Toxic Resolve or in

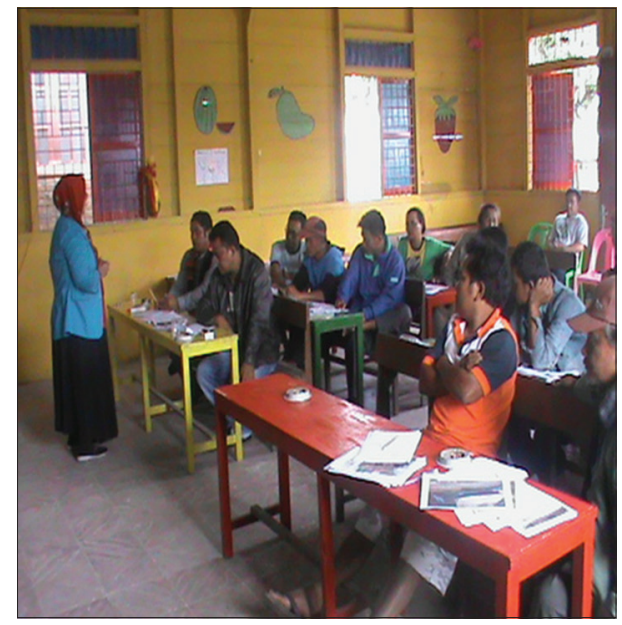

Figure 1: Joint meeting with GEMPAR participants
Bahasa called Gerakan Masyarakat Petani Atas Racun (GEMPAR). This intervention is very simple and easy to implement because it formulated as a solution from determinant analysis pesticide toxicity before. GEMPAR consists of eight movements that act as a form of social empowerment for the farming community. This action was carried out in such a way as to change the awareness of the farming community which uses pesticides inappropriately and correctly accompanied by the farmers slowly switching to using natural pesticides. GEMPAR actions are systematically arranged referring to the following levels of health prevention are: recognizing the hazard of pesticide used, completely personal protection used, paying attention to the wind direction and spraying route, store pesticides in a safely place, safely dispose of the remaining pesticide packaging, personal hygiene, record and report toxicity symptom and going to chemical-free and organic farming. The results show that participants can accept and participate in implementing GEMPAR as a whole in their daily lives action. A well-done of GEMPAR is expected to prevent the risk of pesticide toxicity and create a healthy community (Table 2 ).

Based on the evaluation results, the form of acceptance from GEMPAR has expanded by itself not only in the research locations that apply but also extends to all of the farmers that use pesticides. It also improves the safe behavior of pesticide use of pesticides by procedures that reduced the incidence of toxicity around $84 \%$. Knowledge of working safer and healthier also is increased by about $93 \%$. Farmers also use complete personal protection routinely by $100 \%$ and $60 \%$ of farmers begin to think about avoiding the use of chemical pesticides and switch to safer pesticides that are not even made of chemicals around. Implementation of GEMPAR always shows the increasing of differences changing between the farmer.

\section{Discussion}

Several factors that influence pesticide toxicity are the ignorance of farmers about the toxic effects and unusually personal protection used. They use pesticides based on experience and information from fellow farmers. It based on agricultural products as their income for daily life. Besides, the effects of pesticides felt by farmers are generally temporary and can disappear even though the possibility of reappearance can occur [29], [30], [31], [32], [33]. The results found that the farmers did not pay attention to the procedure. It looks in unsafe behavior that the potential to cause pesticide toxicity. Farmers are routinely exposed to high levels of pesticides, usually much greater than those of consumers. The exposure mainly occurs during the preparation and application of the pesticide 
Table 2: Matrix of GEMPAR formulation changes

\begin{tabular}{|c|c|c|c|}
\hline Initial formulation & First cycle & Second cycle & Third cycle (final formulation) \\
\hline $\begin{array}{l}\text { Recognize the dangers of the } \\
\text { poison used }\end{array}$ & Read the pesticide packaging label & Read the packaging label before using & $\begin{array}{l}\text { Read the dangers and effects of poisons } \\
\text { on pesticide packaging labels }\end{array}$ \\
\hline Use the appropriate PPE & $\begin{array}{l}\text { Use PPE complete with waterproof } \\
\text { material }\end{array}$ & Use complete PPE when using pesticides & Use the complete PPE \\
\hline $\begin{array}{l}\text { Pay attention to the wind } \\
\text { direction when spraying }\end{array}$ & Ignoring the direction of the wind & $\begin{array}{l}\text { Pay attention to the direction of the wind } \\
\text { when spraying and the route/spraying path }\end{array}$ & $\begin{array}{l}\text { Adjust the wind direction and spraying } \\
\text { route/path }\end{array}$ \\
\hline $\begin{array}{l}\text { Store pesticides in a safe } \\
\text { place }\end{array}$ & Store pesticides in closed cabinets & Store pesticides in a closed bucket & Store pesticides in a closed container \\
\hline Plant all remaining pesticides & $\begin{array}{l}\text { Defining and burning the remaining } \\
\text { pesticide packaging }\end{array}$ & $\begin{array}{l}\text { Dispose of the remaining pesticide packaging } \\
\text { in a closed container }\end{array}$ & $\begin{array}{l}\text { Dispose of the remaining pesticide } \\
\text { packaging in a closed container }\end{array}$ \\
\hline $\begin{array}{l}\text { Report poisoning complaints } \\
\text { immediately }\end{array}$ & $\begin{array}{l}\text { Understand how to use the SEDARA } \\
\text { card }\end{array}$ & Record complaints on the SEDARA card & Record and report toxicity complaints \\
\hline $\begin{array}{l}\text { Use natural pesticides so } \\
\text { farmers are healthy }\end{array}$ & $\begin{array}{l}\text { Not yet able to understand and switch to } \\
\text { organic farming systems }\end{array}$ & Try entering the organic conversion stage & Going to an organic farming system \\
\hline
\end{tabular}

PPE: Personal Protective Equipment; GEMPAR: Gerakan masyarakat petani atas racun

spray solutions and during the cleaning-up of spraying equipment. The farmers could be exposed when mix, load, and spray pesticides due to spills and splashes, direct spray contact as a result of faulty or missing protective equipment, or even drift. However, farmers can be also exposed to pesticides even when performing activities not directly related to pesticide use. Understanding farmers' perceptions of the risk of pesticides and the determinants of pesticide overuse are important to modify their behavior toward reducing pesticide use [34], [35].

Exposure to the skin, eyes, or other body parts especially cannot be avoided if the plant has grown tall and accidentally exposed because of the changing wind direction when spraying. Skin contact when using pesticides both when mixing, spraying while smoking is one of the significant determining factor for developing health symptoms [36]. Chronic exposure to the body is an event that can gradually dangerous to health. Chronic toxicity is more difficult to detect because it is not immediately felt and does not have specific symptoms and signs. Usually it found in neurotoxic and dermal contact [3], [37], [38], [39], [40]. Spraying patterns in Sumber Mufakat villagers generally do not pay attention to the direction of the wind and are done by going back and forth following the plant beds. That action results in exposing the pesticide sprayed directly on the organs of the eye that are not protected with protective goggles, wind speed, and wind blow as the potential factor to increase the pesticide toxicity [37], [41], [42], [43].

This also happens to farmers in some countries where the farmer feeling uncomfortable after bearing the protective measures which leads to wastage of pesticides and time while doing the spray [44]. Pesticide exposures can be reduced by using PPE in all stages of pesticide handling to minimize pesticide effects on human health. The education of farmers on the hazards of pesticides is crucial for changing wrong behaviors in PPE use. Incorporate of farmers' preferences in extension or health and safety programs to promote safety measures during working with pesticides is important to do [45], [46], [47], [48], [49], [50], [51]. It is a strategy to maximize the protection of pesticide user from hazardous exposures and emphasis on lifelong training and education as crucial for changing wrong behavior in the handling of pesticides [52], [53].

However, awareness among farmers more importance in protecting themselves from hazards associated with pesticide applications is still lacking, especially in Indonesia [48], [54], [55]. Awareness of farmers and authorities needs to be raised regarding the use of protective equipment and correct in handling pesticides; also, there should be strict enforcement of existing pesticide regulations and monitoring policies to minimize the current threats related to pesticide hazards to human health and to the environment prevention strategies for reducing occupational pesticide poisoning, regardless of severity, should be recommended to all types of farming and the level of poisoning severity. Occupational safety and health studies show that safety behaviors among farmers can be affected by many factors, with perceptions, attitudes, and self-efficacy playing a major role [34], [56], [57], [58] [59].

The important behavior of pesticide use has to change where the farmers throw the pesticide package littering around the fields even into the ravine that pollutes the environment. Disposal or storage of pesticides must be done in a safe place and away from water and food sources. Acute and passive pesticide toxicity occurrences also are present in farmers' behaviors. The poor disposal and storage of pesticides could be the health hazards that exposed to farmers' health which may be chronic or acute effects. Production, use, storage, packaging, and disposal of packaging after use processes of pesticides should be controlled to reach the safety farmer [60], [61], [62], [63]. Critical for reducing the risk of developing pesticide-related symptoms and conditions and educational training programs are possible that could be used to control the respiratory diseases associated with pesticide exposure in occupational settings [64].

The health effort to prevent pesticide toxicity is still a scourge among the farmers. In general, farmers have experienced apathetic behavior toward government programs. It caused the top-down management and instantaneous without any definite continuation. The gaps arising from government 
programs proclaimed by almost all are ignored by farmers. The apathetic also because the efforts given are only counseling that does not provide benefits for farmers. The changes that are expected from this social movement activity are a procedure of pesticide use and it will continuously grow the farmers' independence in preventing the risk of toxicity. GEMPAR as an empowerment effort can expand farmer networks both in cross-sector, national, and even international. It is because GEMPAR has been packaged as a model that meets the level of primary, secondary, and tertiary prevention efforts in reducing the risk of toxicity.

There is no bottom-up empowerment strategy before, and GEMPAR, as a new bottom-up social movement, made the farming community can be more independent in preventing the risk of pesticide poisoning. This empowerment strategy is more communicative and easy for farmers to implement, so changing habits to be safer and healthier while using pesticides. GEMPAR is unique and universal that combines the health and agriculture program. It could be developed with collaboration, improve the welfare and health of farmers, and open up more promising new market opportunities. The output of the eight-step movement does not require a relatively high cost and can even help improve the economy of farmers both in terms of agricultural production and the health of farmers. It is the specific reason why GEMPAR is a simple social movement to change the poor pesticide behavior into safety and health pesticide use behavior.

\section{Conclusions}

The effort to prevent pesticide toxicity in community movement formulated in eight actions that meet the level of primary, secondary, and tertiary prevention, namely, GEMPAR. It could be to increase the awareness of farmers as important prevention of toxicity, the creation of healthy farming communities, pesticide use in accordance with procedures, the creation of self-reliance, and the strengthening of farmer networks.

\section{Acknowledgments}

Regards for Lembaga Penelitian Universitas Sumatera Utara supported in funding to elaborate the research. Specially thank you for Sumber Mufakat village leader Mr. Dinis Karo-Karo and Kabanjahe subdistrict leader Mr. Frans Leonardo Surbakti support to develop the GEMPAR movement as one of pesticide exposure preventive program to reach the healthy farmer and going to free of pesticide. Thankfully for all participants that contribute as agent of change and support the community movement collaboration with steering committee of village Mr. Timur Tarigan, Mr. Japet Tarigan, and Mrs. Nurida.

\section{References}

1. Fikri E, Setiani $O$, Nurjazuli N. Hubungan paparan pestisida dengan kandungan arsen (As) dalam urin dan kejadian anemia (Studi: Pada petani penyemprot pestisida di kabupaten Brebes). J Kesehat Lingkung Indones. 2012;11(1):29-37. https://doi. org/10.14710/jkli.16.2.63-69

2. World Health Organization. World Health Statistics 2017: Monitoring Health for the SDGs, Sustainable Development Goals. Geneva: World Health Organization; 2017. https://doi. org/10.2471/blt.15.165027

3. Zhang X, Zhao W, Jing R, Wheeler K, Smith GA, Stallones L, et al. Work-related pesticide poisoning among farmers in two villages of Southern China: A cross-sectional survey. BMC Public Health. 2011;11(1):429. https://doi.org/10.1186/1471-2458-11-429 PMid:21639910

4. Purwati A. Pestisida Ganggu Kesehatan Petani; 2010. Available from: http://www.beritabumi.or.id/penelitian-panap-pestisidaganggu-kesehatan-petani. [Last accessed on 2015 Mar 06]. https://doi.org/10.15294/kemas.v10i2.3387

5. United Nations Children's Fund. Understanding the Impact of Pesticides on Children: A Disccussion Paper. New York, USA: United Nations Children's Fund; 2018. https://doi.org/10.18356/ ef9029fc-en

6. Sukmawati A, Maharani IP. Hubungan antara perilaku dalam pengelolaan pestisida dengan aktivitas enzim cholinesterase darah pada petani cabe di desa santana mekar kecamatan cisayong kabupaten Tasikmalaya. J Ekol Kesehat. 2004;3(2):809. https://doi.org/10.33368/woh.v0i0.285

7. Eliza T, Hasanuddin T, Situmorang S. Perilaku petani dalam penggunaan pestisida kimia (kasus petani cabai di pekon gisting atas kecamatan gisting kabupaten Tanggamus). J IImu IImu Agribisnis. 2013;1(4):334-42. https://doi.org/10.32487/ jshp.v4i1.783

8. Prijanto TB, Nurjazuli N, Sulistiyani S. Analisis faktor risiko keracunan pestisida organofosfat pada keluarga petani hortikultura di kecamatan ngablak kabupaten Magelang. J Kesehat Lingkung Indones. 2009;8(2):73-8. https://doi. org/10.14710/jkli.16.2.63-69

9. Sinulingga K. Telaah residu organoklor pada wortel Daucus carota L. di kawasan sentra kab. Karo Sumut. J Sist Tek Ind. 2006;7(1):92-7.

10. Aktar W, Sengupta D, Chowdhury A. Impact of pesticides use in agriculture: Their benefits and hazards. Interdiscip Toxicol. 2009;2(1):1-12. https://doi.org/10.2478/v10102-009-0001-7 PMid:21217838

11. Lu FC. Toksikologi Dasar (Asas, Organ Sasaran, dan Penilaian Resiko). Edisi Kedu. Jakarta: Universitas Indonesia Press; 2006.

12. Munawir K. Pestisida organoklorin di perairan teluk klabat pulau bangka. Oseanol Limnol Indones. 2010;36(1):1-19.

13. Karyadi K. Dampak penggunaan pupuk dan pestisida yang berlebihan terhadap kandungan residu tanah pertanian bawang merah di kecamatan gemuh kabupaten Kendal. Agromedia. 2008;26(1):10-9. https://doi.org/10.14710/jil.9.1.1-9 
14. Munawir K. Pemantauan kadar pestisida organoklorin di beberapa muara sungai di perairan teluk Jakarta. Oseanol Limnol Indones. 2005;37:13-23.

15. Dinas Kesehatan Kabupaten Karo. Data Pemeriksaan Cholinesterase Pengguna Pestisida Kabupaten Karo Tahun 2008. Kabanjahe: Subdin P2P \& PL, Dinas Kesehatan Kabupaten Karo; 2008. https://doi.org/10.33085/jkg.v2i3.4436

16. Rumah Sakit Umum Kabanjahe. Data Pasien Intoksikasi Periode Januari-Oktober 2017: Rekam Medik Rumah Sakit Umum Kabanjahe Kabupaten Karo. Kabanjahe; Rumah Sakit Umum Kabanjahe; 2018. https://doi.org/10.22146/bkm.27301

17. Moekasan TK, Prabaningrum L. Penggunaan Pestisida Berdasarkan Konsepsi Pengendalian Hama Terpadu (PHT). Lembang, Bandung Barat: Yayasan Bina Tani Sejahtera; 2011. p. 45.

18. Setiawan DA, Redjeki ES, Nasution Z. Analisis proses pembelajaran dalam konsep pemberdayaan kelompok tani. J Pendidik. 2017;2(8):1077-80.

19. Arfan A, Araswaty A. Pkm pemberdayaan petani bawang merah lokal palu melalui penerapan model SLPHT di desa wombo kecamatan tanantovea kab. Donggala provinsi sulawesi Tengah. J Pengabdi Masy. 2018;1(10):14-9. https://doi.org/10.31970/ abditani.v1i0.8

20. Kementerian Kesehatan Republik Indonesia. Entaskan Kemiskinan Desa, Kementerian Pertanian Canangkan Program Bekerja. Jakarta: Kementerian Kesehatan Republik Indonesia; 2018. Available from: http://www.depkes.go.id/pdf. php?id=18042300006. [Last accessed on 2019 Feb 04]. https:// doi.org/10.33007/inf.v4i3.1549

21. Kurniasari L, Hartati I, Riwayati I. Pemberdayaan masyarakat petani dengan penerapan teknologi pembuatan insektisida nabati dari limbah penyulingan daun nilam. Momentum. 2009;5(2):41-5

22. Sumarti T, Nasdian FT, Pranadji T, Rachman HP, Sonaji R, Masithoh S. Model Pemberdayaan Petani dalam Mewujudkan Desa Mandiri dan Sejahtera. Ringkasan Eksekutif Hasil-Hasil Penelitian 2007, Kerjasama Kemitraan Penelitian Pertanian dengan Perguruan Tinggi (KKP3T). Bogor, Indonesia: Bogor Agricultural University; 2007. https://doi.org/10.6066/ jtip.2016.27.2.175

23. Syahyuti S. Relevansi konsep dan gerakan pertanian keluarga (Family Farming) serta Karakteristiknya di Indonesia. Forum Penelit Agro Ekon. 2016;34(2):87-101. https://doi.org/10.21082/ fae.v34n2.2016.87-101

24. Tanziha I. Model pemberdayaan petani menuju ketahanan pangan keluarga. J Gizi Pangan. 2011;6(1):90-9. https://doi. org/10.25182/jgp.2011.6.1.90-99

25. Soesilowati E, Indriyanti DR, Widiyanto W. Model corporate social responsibility dalam program pemberdayaan petani hortikultura. J Ekon Pembang. 2011;12(1):102-17. https://doi. org/10.23917/jep.v12i1.209

26. Koch T, Kralik D. Participatory Action Research in Health Care. Oxford, England: Blackwell Publishing; 2009.

27. Stringer ET. Action Research. $2^{\text {nd }}$ ed. Thousand Oaks, USA: SAGE Publications; 1999.

28. Yusuf AM. Metode Penelitian Kuantitatif, Kualitatif, dan Penelitian Gabungan. Jakarta: Prenadamedia Group; 2016.

29. Mahyuni EL, Harahap U. The health belief model in prevention pesticide toxicity. Glob J Health Sci. 2020;12(6):135-44. https:// doi.org/10.5539/gjhs.v12n6p135

30. Fan L, Niu H, Yang X, Qin W, Bento CP, Ritsema CJ, et al. Factors affecting farmers' behaviour in pesticide use: Insights from a field study in Northern China. Sci Total Environ. 2015;537:360-8. https://doi.org/10.1016/j.scitotenv.2015.07.150 PMid:26282770

31. Riccò M, Vezzosi L, Gualerzi G. Health and safety of pesticide applicators in a high income agricultural setting: A knowledge, attitude, practice, and toxicity study from North-Eastern Italy. $J$ Prev Med Hyg. 2018;59(3):E200-11.

PMid:30397676

32. Akter M, Fan L, Rahman MM, Geissen V, Ritsema CJ. Vegetable farmers' behaviour and knowledge related to pesticide use and related health problems: A case study from Bangladesh. J Clean Prod. 2018;200:122-3. https://doi.org/10.1016/j. jclepro.2018.07.130

33. Mahyuni EL, Yustina I, Sudaryati E. Safety talk and check to prevent pesticide toxicity among farmer. Int J Public Heal Sci. 2017;6(4):293-8. https://doi.org/10.11591/ijphs.v6i4.9113

34. Damalas CA, Koutroubas SD. Farmers' exposure to pesticides: Toxicity types and ways of prevention. Toxics. 2016;4(1):1-10. https://doi.org/10.3390/toxics4010001 PMid:29051407

35. Jallow MF, Awadh DG, Albaho MS, Devi VY, Thomas BM Pesticide knowledge and safety practices among farm workers in Kuwait: Results of a survey. Int J Environ Res Public Health. 2017;14(4):340. https://doi.org/10.3390/ijerph14040340 PMid:28338612

36. Sekiyama M, Tanaka M, Gunawan B, Abdoellah O, Watanabe C Pesticide usage and its association with health symptoms among farmers in rural villages in West Java, Indonesia. Environ Sci. 2007;14:23-33. PMid: 18382412

37. Mahyuni EL. Faktor risiko dalam penggunaan pestisida terhadap keluhan kesehatan pada petani di kecamatan berastagi kabupaten karo 2014. J Kesmas. 2015;9(1):79-89. https://doi. org/10.12928/kesmas.v9i1.1554

38. Nurulain MU, Syed Ismail SN, Abidin EZ, How V. Pesticide application, dermal exposure risk and factors influenced distribution on different body parts among agriculture workers. Malays J Public Heal Med. 2017;1:123-32.

39. Macfarlane E, Carey R, Keegel T, El-Zaemay S, Fritschi L. Dermal exposure associated with occupational end use of pesticides and the role of protective measures. Saf Health Work. 2013;4(3):136-41. https://doi.org/10.1016/j.shaw.2013.07.004 PMid:24106643

40. Mwabulambo SG, Mrema EJ, Ngowi AV, Mamuya S. Health symptoms associated with pesticides exposure among flower and onion pesticide applicators in Arusha Region. Ann Glob Heal. 2018;84(3):369-79. https://doi.org/10.29024/aogh.2303 PMid:30835378

41. Mahyuni EL, Sinaga MM. Health impact of pesticide using method at sprayed worker farmer in Sumber Mufakat Village, Karo. In: Advances in Health Sciences Research. Switzerland: Atlantis Press; 2017. p. 285-9. https://doi.org/10.2991/ phico-16.2017.28

42. Osang AR, Lampus BS, Wuntu AD. Hubungan antara masa kerja dan arah angin dengan kadar kolinesterase darah pada petani padi pengguna pestisida di desa pangian tengah kecamatan passi timur kabupaten bolaang Mongondow. Pharmacon. 2016;5(2):151-7. https://doi.org/10.35800/jjs.v10i2.25003

43. Desmarteau DA, Ritter AM, Hendley P, Guevara MW. Impact of wind speed and direction and key meteorological parameters on potential pesticide drift mass loadings from sequential aerial applications. Integr Environ Assess Manag. 2020;16(2):197210. https://doi.org/10.1002/ieam.4221 PMid:31589364

44. Kumari $\mathrm{S}$, Sharma H. The impact of pesticides on farmer's health: A case study of fruit bowl of Himachal Pradesh. Int J Sci Res. 2014;3(11):144-8.

45. Sharifzadeh MS, Damalas CA, Abdollahzadeh G. Perceived usefulness of personal protective equipment in pesticide 
use predicts farmers' willingness to use it. Sci Total Environ. 2017;609(31):517-23. https://doi.org/10.1016/j. scitotenv.2020.137472

PMid:28755601

46. Al Zadjali S, Morse S, Chenoweth J, Deadman M. Personal safety issues related to the use of pesticides in agricultural production in the Al-Batinah Region of Northern Oman. Sci Total Environ. 2015;502:457-61. https://doi.org/10.1016/j. scitotenv.2014.09.044

PMid:25282255

47. DellaValle CT, Andreotti G, Alavanja MC, Hoppin JA, Hines CJ. Risk-accepting personality and personal protective equipment use within the agricultural health study. J Agromed. 2012;17(3):264-76. https://doi.org/10.1080/10599 24x.2012.686390

PMid:22732067

48. Yarpuz-Bozdogan N. The importance of personal protective equipment in pesticide applications in agriculture. Curr Opin Environ Sci Heal. 2018;4:1-4.

49. Bondori A, Bagheri A, Damalas CA, Allahyari MS. Use of personal protective equipment towards pesticide exposure: Farmers' attitudes and determinants of behavior. Sci Total Environ. 2018;639:1156-63. https://doi.org/10.1016/j. scitotenv.2019.133597

50. Nurcandra F, Mahkota R, Shivalli S. Effect of personal protective equipment during pesticide application to neurological symptoms in farmers in Purworejo District, Indonesia. Kesmas Natl Public Heal J. 2018;12(4):165-71. https://doi.org/10.21109/ kesmas.v12i4.1695

51. Snelder DJ, Masipiqueña MD, De Snoo GR. risk assessment of pesticide usage by smallholder farmers in the Cagayan Valley (Philippines). Crop Prot. 2008;27(3-5):747-62. https://doi. org/10.1016/j.cropro.2007.10.011

52. Damalas CA, Abdollahzadeh G. Farmers' use of personal protective equipment during handling of plant protection products: Determinants of implementation. Sci Total Environ. 2016;571:730-6. https://doi.org/10.1016/j.scitotenv.2016.07.042 PMid:27425442

53. Levesque DL, Arif AA, Shen J. Effectiveness of pesticide safety training and knowledge about pesticide exposure among hispanic farmworkers. J Occup Environ Med. 2012;54(12):15506. https://doi.org/10.1097/jom.0b013e3182677d96 PMid:23169274

54. Yuantari MG, Van Gestel CA, Van Straalen NM, Widianarko B, Sunoko HR, Shobib MN. Knowledge, attitude, and practice of indonesian farmers regarding the use of personal protective equipment against pesticide exposure. Environ Monit Assess. 2015;187(3):142. https://doi.org/10.1007/s10661-015-4371-3 PMid:25716528

55. Wang W, Jin J, He R, Gong H. Gender differences in pesticide use knowledge, risk awareness and practices in Chinese farmers. Sci Total Environ. 2017;590-591:22-8. https://doi. org/10.1016/j.scitotenv.2017.03.053

PMid:28285132

56. Rezaei R, Damalas CA, Abdollahzadeh G. Retracted: Understanding farmers' safety behaviour towards pesticide exposure and other occupational risks: The case of Zanjan, Iran. Sci Total Environ. 2018;616-617:1190-8. https://doi. org/10.1016/j.scitotenv.2020.137471

PMid:29107371

57. Saha S, Adhikary M, Gangopadhyay A, Sarkar S, Brahmachari K Impact of chemical pesticides on environment-a farm level case study. J Interacad. 2016;20(4):452-8.

58. Kim JH, Kim J, Cha ES, Ko Y, Kim DH, Lee WJ. Work-related risk factors by severity for acute pesticide poisoning among male farmers in South Korea. Int J Environ Res Public Health. 2013;10(3):1100-12. https://doi.org/10.3390/ijerph10031100 PMid:23493034

59. Bagheri A, Emami N, Allahyari MS, Damalas CA. Pesticide handling practices, health risks, and determinants of safety behavior among Iranian apple farmers. Hum Ecol Risk Assess Int J. 2018;24(8):2209-23. https://doi.org/10.1080/10807039.20 18.1443265

60. Loha KM, Lamoree M, Weiss JM, De Boer J. Import, disposal, and health impacts of pesticides in the East Africa Rift (EAR) zone: A review on management and policy analysis. Crop Prot. 2018;112:322-31. https://doi.org/10.1016/j.cropro.2018.06.014

61. Ranjan R, Neupane K, Wantamutte AS, Banjade B, Kushwaha N, Neupane R, et al. Practice of pesticides use among the farmers of Kangrali Village in Belgaum-a cross-sectional study. Int $\mathrm{J}$ Interdiscip Multidiscip Stud. 2014;1(5):202-7.

62. Darçın ES, Darçın M. Health effects of agricultural pesticides. Biomed Res. 2017;1:S13-7.

63. Adriyani R. Usaha pengendalian pencemaran lingkungan akibat penggunaan pestisida pertanian. J Kesehat Lingkung. 2006;3(1):95-106.

64. Ye M, Beach J, Martin JW, Senthilselvan A. Occupational pesticide exposures and respiratory health. Int $\mathrm{J}$ Environ Res Public Health. 2013;10(12):6442-71. https://doi.org/10.3390/ ijerph10126442

PMid:24287863 